\title{
Current situation and challenges regarding biosimilars in Japan: an example of trastuzumab biosimilars for breast cancer
}

\author{
Fumikata Hara ${ }^{1}$, Kentaro Tajima*,2 \& Kosuke Tanabe ${ }^{2}$ \\ ${ }^{1}$ Department of Breast Oncology, National Hospital Organization Shikoku Cancer Center, Ehime, Japan \\ ${ }^{2}$ Medical Affairs, Pfizer Japan Inc., Tokyo, Japan \\ *Author for correspondence: Tel.: +81 35309 7000; Kentaro.Tajima@pfizer.com
}

\begin{abstract}
Biologics have dramatically changed breast cancer treatment, and trastuzumab has been an essential treatment drug for HER2-positive breast cancer. The introduction of trastuzumab biosimilar offers the potential to deliver long-term cost savings plus efficiencies for healthcare systems in Japan. The goal of biosimilar development is to demonstrate comparability to the original biologic with a different development concept from that of the original biologic. Hence, a better understanding of the biosimilar itself is urgently needed for appropriate adoption and the integration of trastuzumab biosimilars into oncology clinical practice by all stakeholders. This article focuses on the current situation of biosimilars and future perspectives in Japan by using the trastuzumab biosimilar as an example.
\end{abstract}

First draft submitted: 26 December 2018; Accepted for publication: 29 January 2019; Published online: 15 February 2019

Keywords: biologics $\bullet$ biosimilar $\bullet$ breast cancer $\bullet$ development concept $\bullet$ healthcare system $\bullet$ Japan $\bullet$ trastuzumab

Biologics developed and manufactured for identified target molecules are expected to have target-specific actions. Treatment outcomes for a variety of diseases such as cancer and autoimmune diseases have been dramatically improved by biologics to date, and breast cancer is no exception. The development and manufacturing of biologics involve the use of microorganisms and cultured cells, requiring cutting-edge technologies. The huge cost incurred for the development and manufacturing processes is reflected in the drug price, and the average cost of developing a biologic is estimated to be approximately US $\$ 1.9$ billion [1]. The increased use of biologics is one reason for increasing drug costs in Japan [2]. The increase in antitumor drug costs by $0.77 \%$ is the leading cause of the overall increase in drug costs in advanced medical care [3]. Expectations for biosimilars, which are less-expensive pharmaceuticals with comparable quality, safety and efficacy to those of the original biologics, have increased as one possible solution to optimize drug costs resulting in the reduction in social security payments in Japan. This article discusses the current use of biosimilars and future issues for taking advantage of biosimilars in Japan by using the trastuzumab biosimilar for breast cancer treatment as an example.

\section{Breast cancer treatment \& biologics}

Epidemiology of breast cancer in Japan

The number of female breast cancer patients in Japan was 76,257 as of 2014. Breast cancer mortality was 14,285 as of 2017. Breast cancer is the top specific cancer affecting Japanese women and the fifth leading cause of death among them. The number of breast cancer patients and mortality continues to increase [4]. Breast cancer has become a social issue because its incidence peaks among women in their late 40s to early 50s [4]. Most breast cancers are operable with no distant metastasis at diagnosis, and combined modality therapy, including surgery, is used for treatment. Recurrent breast cancer, seen in $20-30 \%$ of patients, is extremely difficult to cure; these patients will receive drug therapy to prolong their lives and maintain quality of life.

Future Medicine 


\begin{tabular}{|c|c|c|c|c|c|c|c|c|}
\hline Product & $\begin{array}{l}\text { ClinicaTrials.Gov } \\
\text { Identifier }\end{array}$ & Phase & Design & Intervention & Population & $\begin{array}{l}\text { Primary end } \\
\text { point }\end{array}$ & $\begin{array}{l}\text { Approval status } \\
\text { in Japan }\end{array}$ & Ref. \\
\hline $\begin{array}{l}\text { CT-P6 } \\
\text { (Celltrion/Nippon } \\
\text { Kayaku) }\end{array}$ & NCT02162667 & III & $\begin{array}{l}\text { Randomized, DB } \\
\text { parallel group }\end{array}$ & $\begin{array}{l}\text { CT-P6 or Trast }+ \\
\text { Doc } \rightarrow \text { CT-P6 or } \\
\text { Trast }+ \text { FEC }\end{array}$ & $\mathrm{N}=549(\mathrm{EBC})$ & $\operatorname{tpCR}$ & Approved & {$[13,14]$} \\
\hline $\begin{array}{l}\text { ABP980 } \\
\text { (Amgen/Daiichi } \\
\text { Sankyo) }\end{array}$ & NCT01901146 & III & $\begin{array}{l}\text { Randomized, DB } \\
\text { parallel group }\end{array}$ & $\begin{array}{l}\mathrm{Epi}+\mathrm{Cy} \rightarrow \mathrm{ABP} \\
980 \text { or Trast }+ \\
\mathrm{Pac}\end{array}$ & $\mathrm{N}=725(\mathrm{EBC})$ & $\mathrm{tpCR}$ & Approved & {$[15,16]$} \\
\hline \multirow[t]{2}{*}{$\begin{array}{l}\text { PF-05280014 } \\
\text { (Pfizer) }\end{array}$} & NCT01989676 & III & $\begin{array}{l}\text { Randomized, DB } \\
\text { parallel group }\end{array}$ & $\begin{array}{l}\text { PF-05280014 or } \\
\text { Trast + Pac }\end{array}$ & $\mathrm{N}=707(\mathrm{MBC})$ & ORR & \multirow[t]{2}{*}{ Approved } & \multirow[t]{2}{*}{ [17-20] } \\
\hline & NCT02187744 & III & $\begin{array}{l}\text { Randomized, DB } \\
\text { parallel group }\end{array}$ & $\begin{array}{l}\text { PF-05280014 or } \\
\text { Trast + Doc }+ \\
\text { Carb }\end{array}$ & $N=226(E B C)$ & PK & & \\
\hline $\begin{array}{l}\text { DMB-3111 } \\
\text { (DONG-A } \\
\text { SOCIO/Meiji } \\
\text { Seika Pharma) }\end{array}$ & NCT02100917 & 1 & $\begin{array}{l}\text { Randomized, DB } \\
\text { parallel group }\end{array}$ & $\begin{array}{l}\text { DMB-3111 or } \\
\text { Trast }\end{array}$ & $\mathrm{N}=70(\mathrm{HV})$ & PK & - & {$[21,22]$} \\
\hline $\begin{array}{l}\text { AP063 } \\
\text { (Aprogen/Nichi- } \\
\text { lko) }\end{array}$ & $\mathrm{N} / \mathrm{A}$ & Nonclinical & $\mathrm{N} / \mathrm{A}$ & $\mathrm{N} / \mathrm{A}$ & $\mathrm{N} / \mathrm{A}$ & $\mathrm{N} / \mathrm{A}$ & - & \\
\hline \multicolumn{9}{|c|}{$\begin{array}{l}\text { Asu-no-shinyaku (Technomics, Inc.) was used for the search. Drugs found in a search using the term 'biosimilar', developed in Japan and other countries, and having generic names were } \\
\text { included. (Accessed: } 16 \text { November 2018) } \\
\text { Carb: Carboplatin; Cy: Cyclophosphamide; DB: Double blind; Doc: Docetaxel; EBC: Early breast cancer; Epi: Epirubicin; FEC: 5-fluorouracil/epirubicin/cyclophosphamide; HV: Healthy } \\
\text { volunteer; MBC: Metastatic breast cancer; N/A: Not available; ORR: Objective response rate; Pac: Paclitaxel; PK: Pharmacokinetics; tpCR: Total pathological complete response; Trast: } \\
\text { Trastuzumab. }\end{array}$} \\
\hline
\end{tabular}

\section{Breast cancer treatment \& anti-HER2 therapeutic antibodies}

Drug therapy for breast cancer takes into consideration the subtype determined by the expression of hormone receptors and the HER2. Overexpression or gene amplification of HER2 leads to a dysregulation of signaling that results in uncontrollable growth; the Japanese clinical practice guideline for breast cancer stated that it spreads in about $15-25 \%$ of invasive breast cancers [5]. The prognosis of HER2-positive breast cancer has been dramatically improved by the therapeutic antibody-targeting HER2 protein, the first of its kind developed for cancer treatment. Trastuzumab, the first human monoclonal antibody against the HER2 protein, has an antitumor effect based on the inhibition of growth factor signaling and the antibody-dependent, cell-mediated cytotoxicity. The combination of trastuzumab and chemotherapy is strongly recommended as a standard primary systemic treatment for early breast cancer based on a meta-analysis of randomized clinical trials showing a significant extension of disease-free survival and overall survival (OS) [6]. In addition, a Japanese cohort study showed that outcomes of trastuzumab therapy in HER2-positive early breast cancer were favorable and appeared to be comparable with other studies [7]. Pertuzumab is another anti-HER2 therapeutic antibody with an antitumor effect based on the inhibition of dimerization of HER2 and other HER family members. The Phase III CLEOPATRA study conducted by Roche showed that trastuzumab/pertuzumab/docetaxel treatment, which is currently approved as the standard first-line treatment for HER2-positive metastatic breast cancer, significantly extended the progression-free survival and OS of patients included in the study [8]. Recently, pertuzumab has been approved as an adjuvant treatment for HER2 positive early breast cancer based on the Phase III APHINITY study [9]. Trastuzumab emtansine (T-DM1), trastuzumab bound to a microtubule polymerization inhibitor emtansine (DM1), is an antibody-drug conjugate. The T-DM1 became the standard second-line or subsequent treatment for HER2-positive metastatic breast cancer based on Phase III studies $[10,11]$.

While the anti-HER2 therapeutic antibodies significantly extended the survival of HER2-positive breast cancer patients, the high price of the biologics remains a problem. The American Society of Clinical Oncology issued a statement to stress the importance of evaluating biologics based on cost in addition to efficacy and safety [12]. Expectations for less expensive, quality biosimilars have therefore increased in recent years, and three trastuzumab biosimilars (CT-P6, ABP980 and PF-05280014) have been approved in Japan to date (Table 1).

\section{Concept of biosimilar development}

The definition of biosimilars; biologics are not generics

Unlike chemically synthesized small molecules, biologics are manufactured from organisms through a complicated process. A slight difference in the manufacturing conditions or environment may affect the end product, pro- 


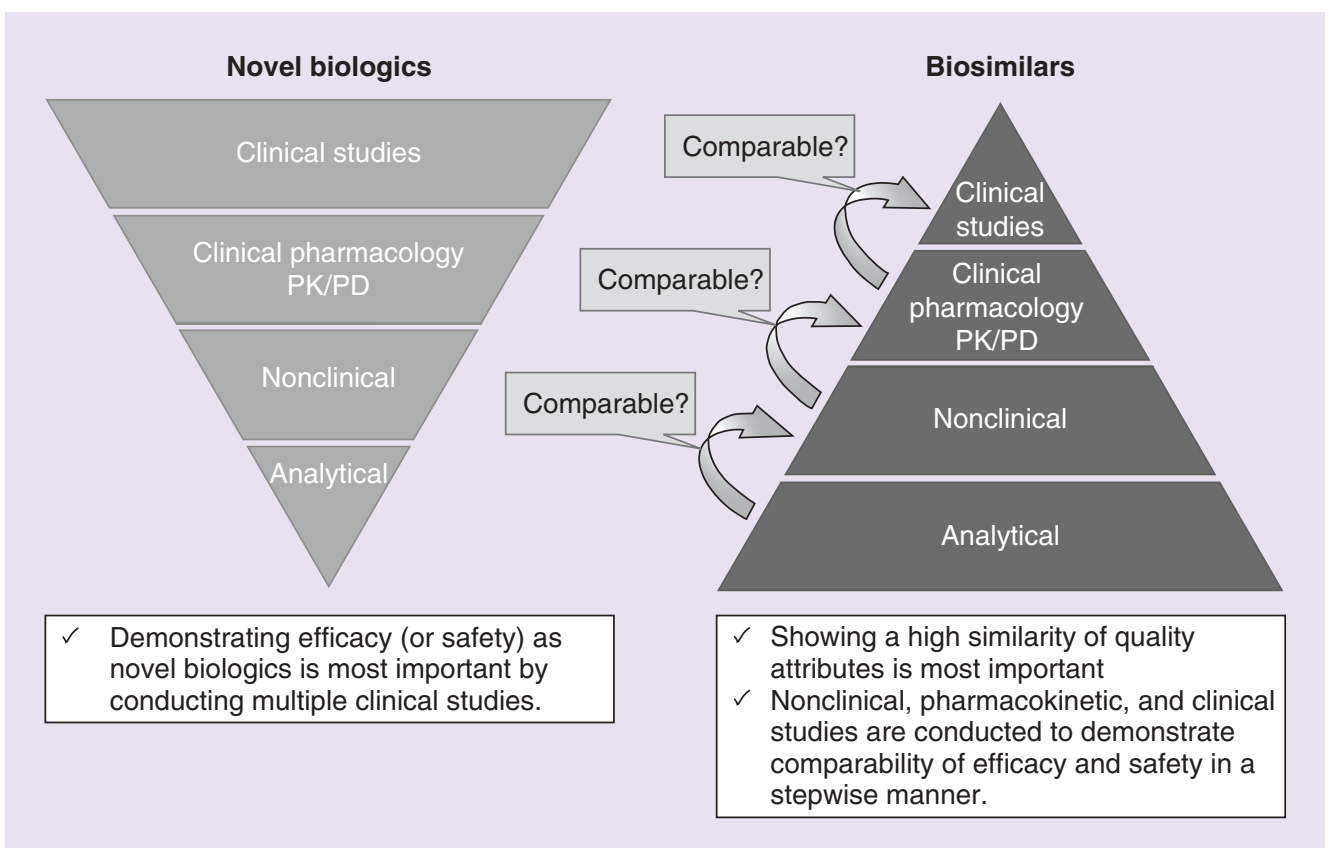

Figure 1. Concepts of biosimilar development.

PK/PD: Pharmacokinetic/pharmacodynamic.

Adapted with permission from [30] ( SAGE Publications (2015).

ducing certain variability. This heterogeneity in quality is acceptable to a certain extent in the quality control of biologics [23,24].

The regulatory authority in Japan defines a biosimilar 'a biotechnological drug product developed to be comparable in regard to quality, safety, and efficacy to an already approved biotechnology-derived product (original biologic) of a different company' [25]. The term 'comparable' is used because the higher order structure of a biosimilar cannot be identical to that of the original biologic due to the characteristic heterogeneity. A generic, in contrast, is a small molecule and can be synthesized to be identical to the original drug. Mixing up biosimilars with generics may cause misunderstandings [26]. Regulatory authorities in the USA, European Union (EU) and Japan have all issued separate regulations and guidelines for biosimilars and generics [27-29]. Although the definitions of biosimilar have slightly different wordings, the concept of a biosimilar is the same among these nations.

\section{The development concept is different between biosimilars \& original biologics}

The goal of biosimilar development is 'to demonstrate that its quality attributes are highly similar and that any differences in the quality attributes of the two biologic products have no adverse impact upon safety or efficacy' [25]. The comparability is evaluated in a stepwise manner in quality characterization and in nonclinical, pharmacokinetic and clinical studies. The comparability is thus evaluated based on the totality of evidence, not based on the results of a specific study. Therefore, showing a high similarity of the biosimilar's quality attributes compared with the original biologic in an extensive quality characterization will be of primary importance. Nonclinical, pharmacokinetic and clinical studies are conducted in a stepwise manner to further evaluate residual uncertainties in quality attributes to demonstrate no changes in the efficacy and safety of the biosimilar (Figure 1) [30,31]. Furthermore, the objective of comparative clinical studies of a biosimilar is to demonstrate the absence of any clinically significant differences and not to reproduce the efficacy as in the clinical studies of the original biologic; therefore, its design is not necessarily the same as that of the original biologic (e.g., end point and sample size).

One of the important concepts of biosimilar development is 'extrapolation of indications'. If a specific indication of the biosimilar has been shown to be comparable with one of the indications of the original biologic and a pharmacological comparability of the other indications can be expected, it may be possible to extrapolate the other approved indications of the original biologic to the biosimilar [25]. The clinical studies of the trastuzumab biosimilar, recently approved in Japan, were conducted in breast cancer patients, but an approval was also granted 


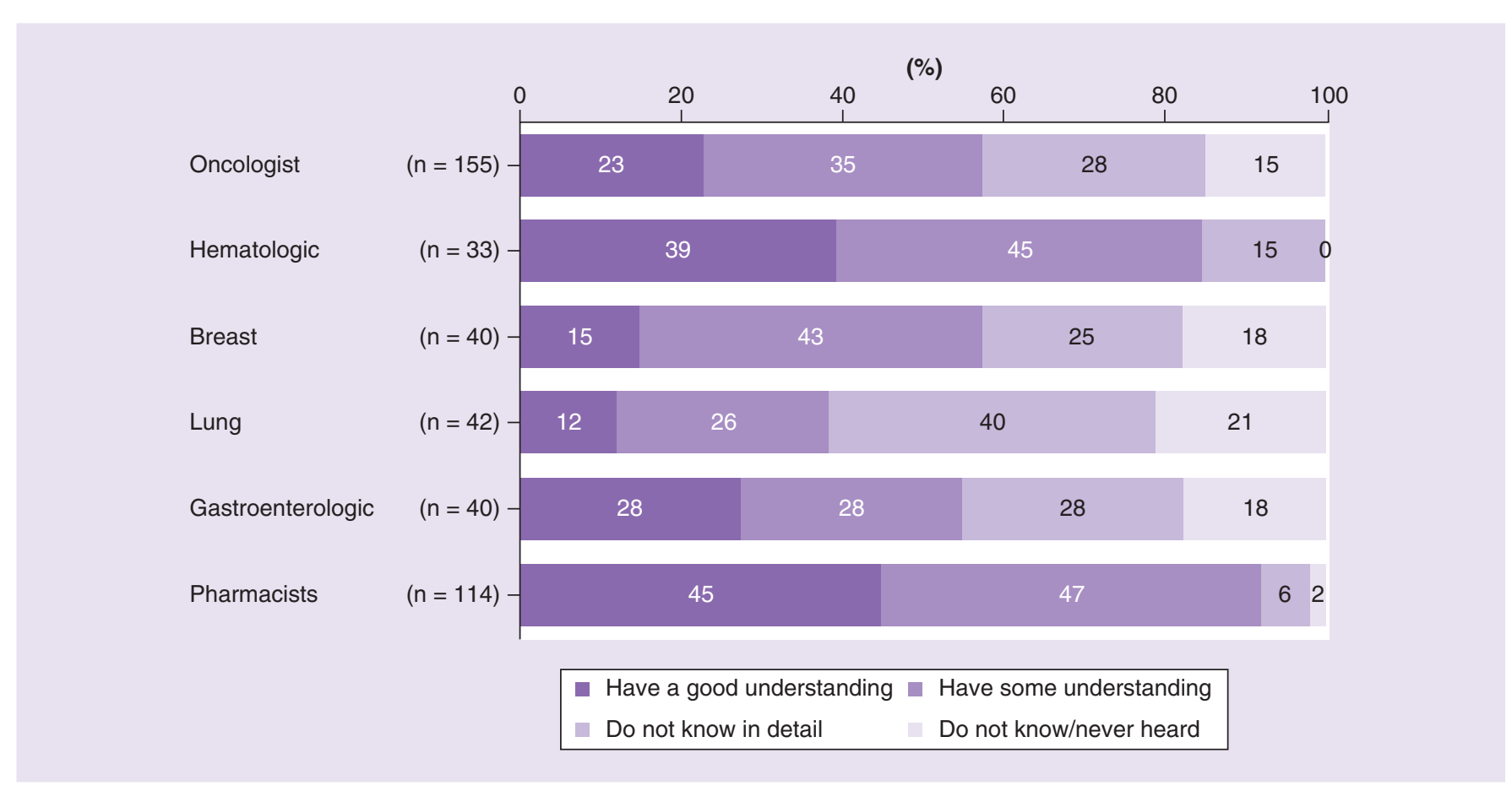

Figure 2. Recognition and understanding of biosimilars by different occupations in Japan. Adapted with permission from [36].

for the indication for gastric cancer based on the comprehensive and scientific evidence, including the mechanism of action [32-34].

\section{Current issues \& perspectives on biosimilars in Japan}

Biosimilars are yet to be recognized \& understood in Japan

The Japanese surveys on the recognition and understanding of biosimilars also showed that physicians, pharmacists and patients were unfamiliar with biosimilars [35,36], similar to the situation overseas [37-39]. According to the survey [36, $43 \%$ of oncologists expressed unfamiliarity with biosimilars (Figure 2). A number of medical professionals have voiced their concerns regarding insufficient clinical data. One reason for their concerns may be that the concept of biosimilar development is not understood correctly. As many biosimilars are now available, it is important for medical professionals to recognize and understand biosimilars appropriately to ensure smooth communication to patients.

\section{Educational activities on biosimilars are about to start in Japan}

Various efforts are made to promote the understanding of biosimilars in the USA and EU. The American Society of Clinical Oncology and the European Society for Medical Oncology have issued position statements and guidance for medical oncologists to support decision-making concerning biosimilar treatment in the field of oncology [40,41]. Some educational materials are available to promote the understanding of biosimilars and support communication with patients using proactive educational activities (Table 2) [42].

The educational activities for biosimilars in Japan are behind those in the USA and EU. The Ministry of Health, Labour and Welfare finally revised the Comprehensive Drug Industry Reinforcement Strategy to start educational activities on biosimilars [43]. However, no position statement has been issued nor have biosimilars been included in the treatment guidelines of any of the cancer societies in Japan. Prompt preparation of educational programs initiated by the government and position statements and guidance from relevant cancer societies are awaited to promote the understanding of biosimilars in Japan. 
Table 2. Educational materials on biosimilars used in the USA and European Union.

\begin{tabular}{|c|c|c|}
\hline Resource & Publisher & Links \\
\hline Biosimilars: more treatment choices and innovation & US FDA & http://bit.ly/2ISeGSA \\
\hline $\begin{array}{l}\text { Biosimilars (educational materials for healthcare } \\
\text { professionals) }\end{array}$ & US FDA & $\begin{array}{l}\text { www.fda.gov/Drugs/DevelopmentApprovalProcess/How } \\
\text { DrugsareDevelopedandApproved/ApprovalApplication } \\
\text { s/TherapeuticBiologicApplications/Biosimilars/default.ht } \\
\text { m }\end{array}$ \\
\hline $\begin{array}{l}\text { What I need to know about biosimilar medicines: } \\
\text { information for patients }{ }^{\dagger}\end{array}$ & European Commission & http://ec.europa.eu/DocsRoom/documents/26643 \\
\hline $\begin{array}{l}\text { Biosimilars in the EU. Information guide for } \\
\text { healthcare professionals }\end{array}$ & European Commission & http://ec.europa.eu/DocsRoom/documents/22924 \\
\hline $\begin{array}{l}\text { Biosimilars Toolkit. An information and advocacy } \\
\text { toolkit for patients' organizations }\end{array}$ & International Alliance of Patients' Organizations & www.iapo.org.uk/biosimilars-toolkit \\
\hline Resources & Patients for Biologics Safety \& Access & www.biosimsafety.org/resources \\
\hline What is new & Medicines for Europe & $\begin{array}{l}\text { www.medicinesforeurope.com/biosimilar-medicines/wh } \\
\text { ats-new/ }\end{array}$ \\
\hline Biosimilars & National Rheumatoid Arthritis Society & www.nras.org.uk/biosimilars \\
\hline \multicolumn{3}{|c|}{$\begin{array}{l}{ }^{\dagger} \text { Available in } 23 \text { official European languages. } \\
\text { Adapted with permission from [42] (C) Future Medicine Ltd (2018). }\end{array}$} \\
\hline
\end{tabular}

The cost advantage of biosimilars for patients may not be utilized in Japan's healthcare system In Japan, it is mandatory for all citizens to be enrolled in public health insurance, classified as employment-based health insurance and national health insurance. Considering the current universal health insurance coverage system, everyone can access high-quality medical services with low costs and have free access of medical institution. In order to maintain universal health insurance coverage, the Japanese government provides a public subsidy and controls the price of medical services including drugs [44]. Once a drug has been approved, the price of the drug will be fixed by the Japanese government and will be reimbursed in almost all cases. For example, the price of a biosimilar is usually $70 \%$ that of the original biologic in Japan [45]. Thus, Japanese breast cancer patients have access to advanced therapies with trastuzumab whether they are diagnosed with early breast cancer or metastatic breast cancer with an overexpression of HER2.

The 'high-cost medical expense benefit system', which puts a cap on the out-of-pocket (OOP) cost of medical expenses according to the patient's age and annual income is another unique social security system in Japan [46]. In breast cancer treatment, if the high-cost medical expense benefit system is used for the concomitant use of trastuzumab with other expensive drugs such as pertuzumab or chemotherapy, the use of trastuzumab biosimilar may not result in the reduction of OOP costs (Figure 3). In addition, the difficulty in calculating the patient copayment due to the complexity of this system is also a problem. The need for healthcare reform has been pointed out to improve the environment for the use of biosimilars [47].

\section{The Japanese government has just started to promote the use of biosimilars}

However, a variety of recent documents issued by the Japanese government mentioned supportive measures for the development of biologics and biosimilars [48,49]. The Basic Policy on Economic and Fiscal Management and Reform issued in 2017 states,"while enhancing supporting measures for the research and development of biopharmaceuticals and biosimilar pharmaceuticals, the government will disclose the effective amount of optimization of medical costs and value share of biosimilar pharmaceuticals and aim to double the number of biosimilar pharmaceuticals (number of ingredients basis) by the end of fiscal 2020" [48]. This statement points to the specific direction Japan is heading to increase the use of biosimilars, taking a big first step toward using biosimilars to their full potential in Japan. The environment for healthcare policy making is expected to improve further for the use of biosimilars, including streamlining the high-cost medical expense benefit system.

\section{Conclusion}

Biologics have dramatically changed breast cancer treatment and will remain as essential drugs. Biosimilars that are potentially less expensive are expected to bolster the Japanese healthcare system. Several trastuzumab biosimilars became available for breast cancer patients in Japan; however, the environment is still too immature to take full advantage of the drugs. Vigorous educational activities and provision of information is anticipated in Japan as in the USA and EU to correctly understand and properly use biosimilars. Additionally, in order to increase 


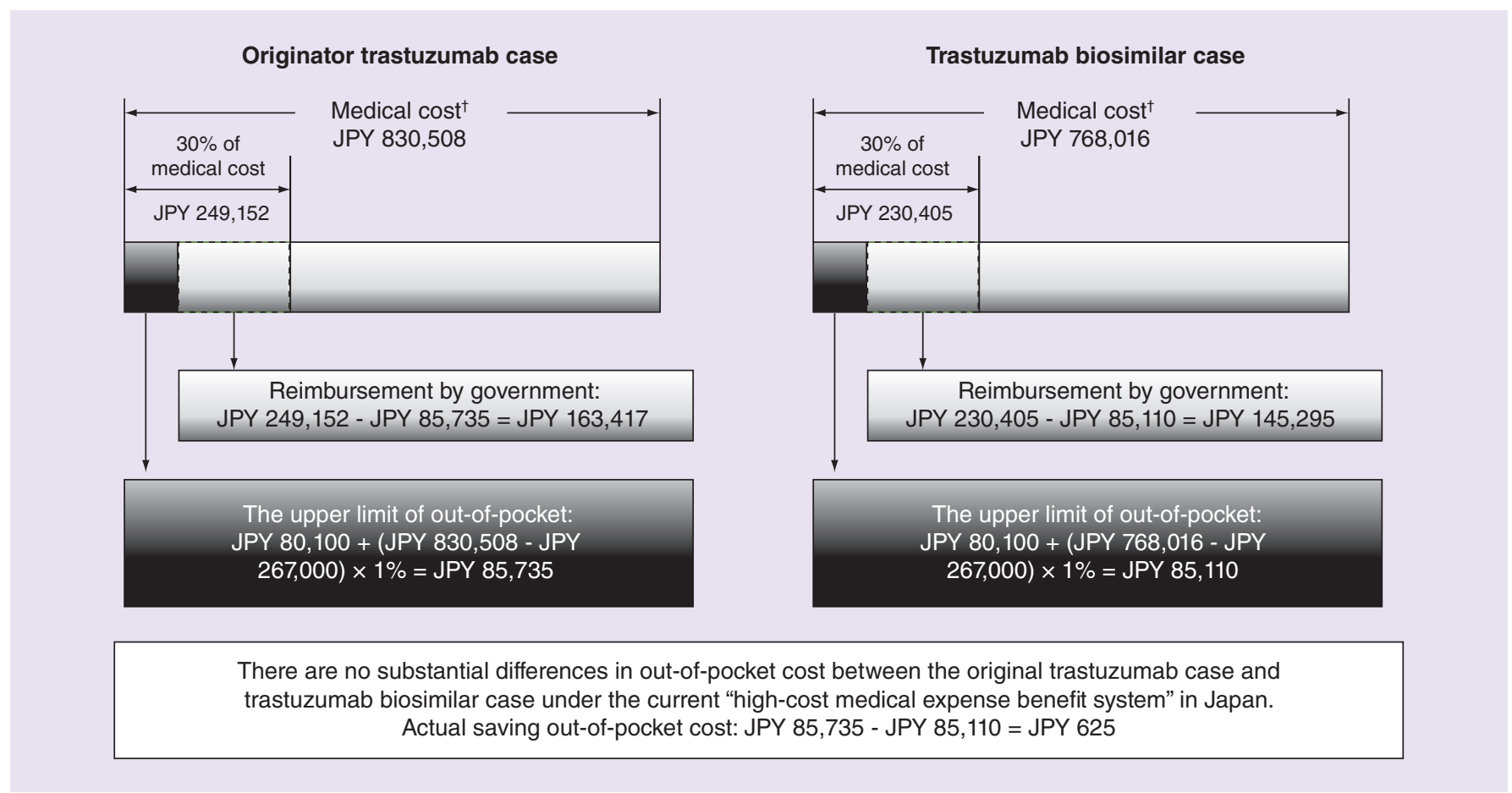

Figure 3. An example of granting the high-cost medical expense benefit. Background assumptions are as follows: age is in 50 years and annual income is between 3.7 million JPY and 7.7 million JPY; height: $157 \mathrm{~cm}$, weight: $55 \mathrm{~kg}$, body surface area: 1.54 m² (mean values for women in their 50 years in Japan); for metastatic breast cancer, the regimen is 'trastuzumab + pertuzumab + docetaxel'; the price of trastuzumab biosimilar is assumed to be $70 \%$ of original trastuzumab based on a Ministry of Health, Labour and Welfare document; under the healthcare system in Japan, $70 \%$ of the medical cost is reimbursed. Based on these assumptions, a vial of trastuzumab (150 mg), three vials of trastuzumab $(60 \mathrm{mg})$, a vial of pertuzumab $(420 \mathrm{mg})$, a vial of docetaxel $(80 \mathrm{mg})$ and two vials of docetaxel (20 mg) are needed per visit. Then, the regimen with original trastuzumab will cost 830,508 JPY per month, and that with trastuzumab biosimilar will cost 768,016 JPY. The upper limit for a patient's out-of-pocket cost per month is calculated as ' $80,100 \mathrm{JPY}+$ (medical expenditure $267,000 \mathrm{JPY}) \times 1 \%$ '.

†Other expenditures (e.g., doctor's consultation fee, experiment fee and hospitalization fee) are not considered in this calculation because these expenditures vary in each patient.

JPY: Japanese Yen.

Adapted with permission from [44] (c) website of Ministry of Health, Labour and Welfare (Japanese Government).

the confidence of medical professionals in biosimilars, feedback of the clinical data of biosimilars including postmarketing surveillance in real-world settings should be given. Considering the current healthcare system in Japan, development of incentives to promote the use of biosimilars is also expected.

\section{Future perspective}

In the near future, various innovative therapies such as antibody-drug conjugates and immune checkpoint inhibitors may be approved and utilized to impact the current standard treatment in the breast cancer field. Since maintaining the current Japanese healthcare system is essential to realize the clinical benefits of these new therapies, to reduce healthcare cost including drug costs will be more and more important. Thus, trastuzumab biosimilars will play an important role in Japanese society. As more healthcare providers and patients gain the right understanding about biosimilars with appropriate information including real-world evidence, trastuzumab biosimilars are expected to be utilized with confidence among them. Eventually, as increasing numbers of biosimilars are approved in Japan, the Japanese government is anticipated to take some measures offering incentives for patients who take biosimilars in terms of OOP cost. 
- Treatment outcomes for a variety of diseases such as cancer and autoimmune diseases have been dramatically improved by biologics to date such as trastuzumab for breast cancer.

- Biosimilars are expected to optimize drug costs resulting in the reduction in social security payments in Japan.

Breast cancer treatment \& biologics

- Breast cancer is the top specific cancer affecting Japanese women and the fifth leading cause of death among them in Japan.

- While the anti-HER2 therapeutic antibodies significantly extended the survival of HER2-positive breast cancer patients, the high price of the biologics remains a problem.

- Expectations for less expensive, quality biosimilars have increased in recent years, and three trastuzumab biosimilars have been approved in Japan to date.

Concept of biosimilar development

- The concept of biosimilar development is the same among European Union (EU), the USA and Japan although the wording of guidelines of biosimilars is slightly different.

- Because of the characteristics of heterogeneity in biologics, showing a high similarity of quality attributes is most important.

- The comparability is evaluated based on the totality of evidence, which is demonstrated by a stepwise manner in quality characterization and in nonclinical, pharmacokinetic and clinical studies.

- The clinical studies of the trastuzumab biosimilar, recently approved in Japan, were conducted in breast cancer patients, but an approval for gastric cancer was granted as 'extrapolation of indications' based on the comprehensive and scientific evidence, including the mechanism of action.

Current issues \& perspectives on biosimilars in Japan

- Physicians, pharmacists and patients were unfamiliar with biosimilars in Japan based on surveys.

- Under the current universal health insurance coverage system and high-cost medical expense benefit system in Japan, the use of biosimilars may not affect the reduction of out of pocket costs.

- Although educational activities for biosimilars in Japan are behind those in the USA and EU, the Ministry of Health, Labour and Welfare has finally started educational activities on biosimilars.

Conclusion

- In Japan, the environment is still immature to take full advantage of biosimilars.

- Vigorous educational activities and the provision of information is anticipated in Japan as in the USA and EU to correctly understand and properly use biosimilars. Development of incentives to promote the use of biosimilars is also expected.

\section{Author contributions}

F Hara contributed to conception of the article and drafting from the viewpoint of a breast cancer specialist. K Tajima contributed to the entire structure of the article and drafting the manuscripts, figures and tables. $\mathrm{K}$ Tanabe contributed to conception and interpretation of the article.

Financial \& competing interests disclosure

F Hara has received speaker's honoraria from Pfizer Japan Inc., Kyowa Hakko Kirin Co., Ltd and Eisai Co., Ltd. K Tajima and K Tanabe are employees of Pfizer Japan Inc. The authors have no other relevant affiliations or financial involvement with any organization or entity with a financial interest in or financial conflict with the subject matter or materials discussed in the manuscript apart from those disclosed.

Translation assistance was provided by Honyaku Center Inc., and preparation of figures/tables was supported by WysiWyg Co., Ltd. Both were funded from Pfizer Japan Inc.

\section{Open access}

This work is licensed under the Attribution-NonCommercial-NoDerivatives 4.0 Unported License. To view a copy of this license, visit http://creativecommons.org/licenses/by-nc-nd/4.0/

\section{References}

Papers of special note have been highlighted as: $\bullet$ of interest; $\bullet \bullet$ of considerable interest

1. Blackstone EA, Joseph PF. The economics of biosimilars. Am. Health Drug Benefits 6(8), 469-478 (2013).

2. Ministry of Health, Labour and Welfare. The 334th general assembly minutes. (2016). www.mhlw.go.jp/stf/shingi2/0000130983.html

3. Central Social Insurance Medical Council, Ministry of Health, Labour and Welfare. Analysis of factors for the increase of medical expenses. (2016). www.mhlw.go.jp/file/05-Shingikai-12404000-Hokenkyoku-Iryouka/0000137953.pdf 
4. National Cancer Center. The latest cancer statics. (2018). https://ganjoho.jp/reg_stat/statistics/stat/summary.html

5. Japanese Breast Cancer Society. What is the purpose and procedures of HER2 test? In: [The Japanese Breast Cancer Society Clinical Practice Guidelines for Breast Cancer 2018 - Epidemiology and Diagnosis (Volume 2)]. Japanese Breast Cancer Society (Ed.). Kanehara-Shuppan Publishers, Tokyo, Japan, 265-268 (2018).

6. Moja L, Tagliabue L, Balduzzi S et al. Trastuzumab containing regimens for early breast cancer. Cochrane Database Syst. Rev. (4), CD006243 (2012).

7. Yamashiro H, Iwata H, Masuda $\mathrm{N}$ et al. Outcomes of trastuzumab therapy in HER2-positive early breast cancer patients. Int. J. Clin. Oncol. 20(4), 709-722 (2015).

8. Baselga J, Cortés J, Kim SB et al. Pertuzumab plus trastuzumab plus docetaxel for metastatic breast cancer. N. Engl. J. Med. 366(2), 109-119 (2012).

9. von Minckwitz G, Procter M, de Azambuja E et al. Adjuvant pertuzumab and trastuzumab in early HER2-positive breast cancer. $N$. Engl. J. Med. 377(2), 122-131 (2017).

10. Verma S, Miles D, Gianni L et al. Trastuzumab emtansine for HER2-positive advanced breast cancer. N. Engl. J. Med. 367(19), 1783-1791 (2012).

11. Krop IE, Kim SB, González-Martín A et al. Trastuzumab emtansine versus treatment of physician's choice for pretreated HER2-positive advanced breast cancer (TH3RESA): a randomised, open-label, Phase III trial. Lancet Oncol. 15(7), 689-699 (2014).

12. Schnipper LE, Davidson NE, Wollins DS et al. American Society of Clinical Oncology statement: a conceptual framework to assess the value of cancer treatment options. J. Clin. Oncol. 33(23), 2563-2577 (2015).

13. ClinicalTrials.gov. Efficacy and safety evaluating study of CT-P6 in HER2 positive early breast cancer. (2017). https://clinicaltrials.gov/ct2/show/NCT02162667

14. Stebbing J, Baranau Y, Baryash V et al. CT-P6 compared with reference trastuzumab for HER2-positive breast cancer: a randomised, double-blind, active-controlled, Phase III equivalence trial. Lancet Oncol. 18(7), 917-928 (2017).

15. Clinical Trials Database: NCT01901146. www.clinicaltrials.gov/ct2/show/NCT01901146

16. von Minckwitz G, Colleoni M, Kolberq HC et al. Efficacy and safety of ABP 980 compared with reference trastuzumab in women with HER2-positive early breast cancer (LILAC study): a randomised, double-blind, Phase 3 trial. Lancet Oncol. 19(7), 987-998 (2017).

17. Clinical Trials Database: NCT01989676. www.clinicaltrials.gov/ct2/show/NCT01989676

18. Clinical Trials Database: NCT02187744. www.clinicaltrials.gov/ct2/show/NCT02187744

19. Pegram MD, Bondarenko I, Zorzetto MMC et al. PF-05280014 (a trastuzumab biosimilar) plus paclitaxel compared with reference trastuzumab plus paclitaxel for HER2-positive metastatic breast cancer: a randomised, double-blind study. Br. J. Cancer 120(2), 172-182 (2017).

20. Lammers PE, Dank M, Masetti R et al. Neoadjuvant PF-05280014 (a potential trastuzumab biosimilar) versus trastuzumab for operable HER2+ breast cancer. Br. J. Cancer. 119(3), 266-273 (2018).

21. Clinical Trials Database: NCT02100917. https://clinicaltrials.gov/ct2/show/NCT02100917?term=NCT02100917\&rank=1

22. Morita J, Tanaka M, Nomoto M et al. Pharmacokinetic bioequivalence, safety, and immunogenicity of DMB-3111, a trastuzumab biosimilar, and trastuzumab in healthy Japanese adult males: results of a randomized trial. BioDrugs 30(1), 17-25 (2016).

23. Kim S, Song J, Park S et al. Drifts in ADCC-related quality attributes of Herceptin ${ }^{\circledR}$ : impact on development of a trastuzumab biosimilar. MAbs 9(4), 704-714 (2017).

24. Schiestl M, Stangler T, Torella C, Cepeljnik T, Toll H, Grau R. Acceptable changes in quality attributes of glycosylated biopharmaceuticals. Nat. Biotechnol. 29(4), 310-312 (2011).

25. Ministry of Health, Labour and Welfare. Guideline for the quality, safety and efficacy assurance of follow-on biologics. (2013). www.pmda.go.jp/files/000153851.pdf

-. Guidance on the requirement for the development of biosimilars in Japan.

26. Declerck P, Danesi R, Petersel D, Jacobs I. The language of biosimilars: clarification, definitions, and regulatory aspects. Drugs 77(6), 671-677 (2017).

27. Wang J, Chow SC. On the regulatory approval pathway of biosimilar products. Pharmaceuticals (Basel) 5(4), 353-368 (2012).

28. US FDA. Improving access to innovative medical therapies. Subtitle A-Biologics Price Competition and Innovation Act; SEC 7002. www.fda.gov/downloads/drugs/ucm216146.pdf

29. European Medicines Agency. Guideline on similar biological medicinal products. (2014). www.ema.europa.eu/docs/en_GB/document_library/Scientific_guideline/2014/10/WC500176768.pdf

- Guidance on the requirement for the development of biosimilars in EU.

30. Ryan AM. Frontiers in nonclinical drug development: biosimilars. Vet. Pathol. 52(2), 419-426 (2015).

31. Socinski MA, Curigliano G, Jacobs I, Gumbiner B, MacDonald J, Thomas D. Clinical considerations for the development of biosimilars in oncology. MAbs 7(2), 286-293 (2015). 
32. Pharmaceuticals and Medical Devices Agency. Evaluation report (Trastuzumab Biosimilar 1). (2018). www.pmda.go.jp/drugs/2018/P20180314003/530191000_5122908013560_A100_1.pdf

33. Pharmaceuticals and Medical Devices Agency. Evaluation report (Trastuzumab Biosimilar 2). (2018). www.pmda.go.jp/drugs/2018/P20181017001/430574000_23000AMX00802_A100_2.pdf

34. Pharmaceuticals and Medical Devices Agency. Evaluation report (Trastuzumab Biosimilar 3). (2018). www.pmda.go.jp/drugs/2018/P20181012001/671450000_23000AMX00800_A100_1.pdf

35. Toyoshima S. Survey for the solution of issues concerning the promotion of biosimilar use (research no. H28-special-designated-012). The Health and Labour Science Research Grant Project, 2016 General and Substudy Report. (2016). https://mhlw-grants.niph.go.jp/niph/search/NIDD00.do?resrchNum=201605010A

- The survey granted by Ministry of Health, Labour and Welfare regarding biosimilars including the awareness and perception of biosimilars in Japan.

36. Tanabe Y, Sugimoto N, Muto M, Fujimoto Y. Field survey on the recognition and intention of using follow-on biologics (biosimilars) in physicians and pharmacists. Prog. Med. 36(2), 291-300 (2016).

37. Zelenetz AD, Ahmed I, Braud EL et al. NCCN biosimilars white paper: regulatory, scientific, and patient safety perspectives. J. Natl Compr. Canc. Netw. 9(4 Suppl.), S1-S22 (2011).

38. Cohen H, Beydoun D, Chien D et al. Awareness, knowledge, and perceptions of biosimilars among specialty physicians. Adv. Ther. 33(12), 2160-2172 (2017).

39. Jacobs I, Singh E, Sewell KL, Al-Sabbagh A, Shane LG. Patient attitudes and understanding about biosimilars: an international cross-sectional survey. Patient Prefer. Adherence 10, 937-948 (2016).

40. Lyman GH, Balaban E, Diaz M et al. American Society of Clinical Oncology statement: biosimilars in oncology. J. Clin. Oncol. 36(12), 1260-1265 (2018).

- The statement regarding biosimilars in oncology from American Society of Clinical Oncology including educational contents.

41. Tabernero J, Vyas M, Giuliani R et al. Biosimilars: a position paper of the European Society for Medical Oncology, with particular reference to oncology prescribers. ESMO Open 1(6), e000142 (2017).

- The first position paper regarding biosimilars in oncology from the European Society for Medical Oncology including educational contents.

42. Janjigian YY, Bissig M, Curigliano G, Coppola J, Latymer M. Talking to patients about biosimilars. Future Oncol. 14(23), 2403-2414 (2018).

43. Ministry of Health, Labour and Welfare. Comprehensive Drug Industry Reinforcement Strategy: drug discovery with future global presence in mind. (2017). www.mhlw.go.jp/stf/houdou/0000189123.html

44. Ministry of Health, Labour and Welfare. An Outline of the Japanese Medical System. (2018). www.mhlw.go.jp/english/policy/health-medical/health-insurance/index.html

-• The material of Ministry of Health, Labour and Welfare to explain the overview of Japanese medical system for English-speaking countries.

45. Ministry of Health, Labour and Welfare. NHI price calculation method. (2018). www.mhlw.go.jp/file/06-Seisakujouhou-12400000-Hokenkyoku/0000193793.pdf

46. Ministry of Health, Labour and Welfare. To patients using the high-cost medical expense benefit system. (2018). www.mhlw.go.jp/stf/seisakunitsuite/bunya/kenkou_iryou/iryouhoken/juuyou/kougakuiryou/index.html

47. Yamanaka H. Hope and challenge for the biosimilars from clinical perspective. Cell 49(9), 443-446 (2017).

48. Cabinet Office. Basic Policy on Economic and Fiscal Management and Reform 2017. (2017). www5.cao.go.jp/keizai-shimon/kaigi/cabinet/2017/2017_basicpolicies_en.pdf

- The basic policy issued by Cabinet Office in Japan including measures for promoting biosimilar development in Japan.

49. Cabinet Office. Basic Policy on Economic and Fiscal Management and Reform 2018. (2018). www5.cao.go.jp/keizai-shimon/kaigi/cabinet/2018/2018_basicpolicies_en.pdf 
